\title{
Polymer models of topological insulators
}

\author{
Boryana Doyle ${ }^{1 *}$, Maxim Imakaev², Geoffrey Fudenberg ${ }^{3}$, Leonid Mirny ${ }^{2,3,4}$ \\ From Epigenetics \& Chromatin: Interactions and processes \\ Boston, MA, USA. 11-13 March 2013
}

\section{Background}

The classic model of eukaryotic gene expression requires spatial contact between a distal enhancer and a proximal promoter. To control gene expression, various models of enhancer-blocking insulators have been proposed, including a decoy model and a topological model [1]. The decoy model suggests that the enhancer or the promoter interacts with an insulating element to prevent enhancer-promoter interactions. The topological model suggests that two or more insulating elements interact with each other to form loops. An outstanding question in the field is whether the topological model is effective at preventing enhancer-promoter interactions.

\section{Materials and methods}

Here we use the polymer model of chromatinized DNA and simulations of Brownian polymer dynamics to study the topological model of enhancer-blocking insulators. We consider one- and two-loop topological elements and assess spatial contacts between various regions of DNA induced or suppressed by an topological elements.

\section{Results}

We find that a loop formed in the region between an enhancer and a promoter in fact facilitates enhancerpromoter contacts and does not act as an enhancerblocking insulator. However, we find that sequestration of an enhancer (or promoter) within a loop is a plausible mechanism for topological insulators. Both the facilitating and insulating effects of topological elements are more dramatic with two-loop elements.

\section{Conclusions}

Our polymer simulations demonstrate that the loopforming topological elements are capable of both facilitating and insulating enhancer-promoter interactions.

'MIT-PRIMES, Massachusetts Institute of Technology, Cambridge, MA, 02139, USA

Full list of author information is available at the end of the article
We note that the biological model of insulator activity around H19 and Igf2 genes in mouse liver cells presented by Kurukuti et al. [2] is a specific realization of the two-loop topological insulator discussed here. Our simulations show that the polymeric nature of chromatin is essential for modulating the action of topological insulators that modulate contact frequency between promoters and enhancers.

\section{Author details}

'MIT-PRIMES, Massachusetts Institute of Technology, Cambridge, MA, 02139, USA. ${ }^{2}$ Department of Physics, Massachusetts Institute of Technology, Cambridge, MA, 02139, USA. ${ }^{3}$ Program in Biophysics, Harvard University, Boston, MA, 02115, USA. ${ }^{4}$ Harvard-MITHealth Sciences and Technology, Massachusetts Institute of Technology, Cambridge, MA, 02139, USA.

Published: 8 April 2013

\section{References}

1. Raab JR, Kamakaka RT: Insulators and promoters: closer than we think. Nat Rev Genet 2010, 11:439-446.

2. Kurukuti S, Tiwari VK, Tavoosidana G, Pugacheva E, Murrell A, Zhao Z, Lobanenkov V, Reik W, Ohlsson R: CTCF binding at the H19 imprinting control region mediates maternally inherited higher-order chromatin conformation to restrict enhancer access to Igf2. Proc Natl Acad Sci USA 2006, 103:10684-10689.

doi:10.1186/1756-8935-6-S1-P127

Cite this article as: Doyle et al:: Polymer models of topological insulators. Epigentics \& Chromatin 2013 6(Suppl 1):P127.

Submit your next manuscript to BioMed Central and take full advantage of:

- Convenient online submission

- Thorough peer review

- No space constraints or color figure charges

- Immediate publication on acceptance

- Inclusion in PubMed, CAS, Scopus and Google Scholar

- Research which is freely available for redistribution
C Biomed Central

C 2013 Doyle et al; licensee BioMed Central Ltd. This is an Open Access article distributed under the terms of the Creative Commons Attribution License (http://creativecommons.org/licenses/by/2.0), which permits unrestricted use, distribution, and reproduction in any medium, provided the original work is properly cited. 